\title{
The Emerging Contextual Effect of University Spin-offs and its Role in Spurring Innovation in Regional Area
}

\author{
Danilo Boffa $^{1}$ and Antonio Prencipe ${ }^{2}$
}

\begin{abstract}
The technology and knowledge transfer from university to industry has raised the attention of policy makers and practitioners as fundamental process in promoting the development of regional innovation and entrepreneurship. University Spin-Offs (USOs), firms established to commercialize the knowledge and technology outcomes of academic research, may constitutes an effective mechanism to improve the innovative dynamics in the regional area. The paper explores the assumption that USOs may partially determine the innovation of regions they are located. From a panel sample of 944 USOs placed in 20 Italian administrative regions, the findings remark that USOs (analysed as [1] number of USOs from each University and [2] patents activity of USOs) has a positive impact on the regional innovation in term of regional patent applications, while a weak role of USOs seems to emerge in term of regional expenditure in $R \& D$.
\end{abstract}

JEL classification numbers: $\mathrm{O} 30, \mathrm{O} 32$.

Keywords: University Spin-Offs, Regional innovation, Entrepreneurial University, Italy.

${ }^{1}$ University of Teramo, via R. Balzarini n. 1., 64100. Teramo, Italy.

${ }^{2}$ University of Teramo, via R. Balzarini n. 1., 64100. Teramo, Italy.

Article Info: Received: September 8, 2021. Revised: September 23, 2021.

Published online: September 26, 2021. 


\section{Introduction}

In view of the widespread expansion that the phenomenon continues to show in Europe, University Spin-Offs (USOs) are considered one of the most qualified entrepreneurial initiatives in offering effective and profitable ways for the diffusion of new technologies and knowledge (Mathisen and Rasmussen, 2019; Miranda, et al., 2018; Fini et al., 2017; Lazzeri and Piccaluga, 2012); as well as they are commonly included among the most active and recommended tools to stimulate the creation and development of knowledge-based economies (Benneworth and Charles, 2005; Sternberg, 2014). As a result of the numerical and dimensional development of these types of businesses, the clarification of the determinants regarding their growth and effects has been definitively integrated into the policy agenda dedicated to the dissemination and promotion of innovation in definite environmental contexts (Siegel, 2018).

In line with the emerging configuration outlined, several studies (Kenney and Patton, 2011; Iacobucci and Micozzi, 2015; Etzkowitz and Ranga, 2015) have emphasized that the creation and dissemination of knowledge by universities should be included among the most significant driving forces for the technological innovation of an economy, both at local and at national scale (Mueller, 2006). Indeed, the declination on the regional dimension of the perspective advanced by the Knowledge Spillover Theory of Entrepreneurship (Audretsch and Lehmann, 2005) suggests that the actual spillover of knowledge and innovation in the local socio-economic environment is strictly dependent on the regional entrepreneurship capital (Guerrero and Urbano, 2012; Audretsch et al., 2008), as well as on the efforts and innovative capacity of local agents: factors that discriminate not only the aptitude of selecting the best business projects, but also the possibility to allocate adequate resources (Friedman and Silberman, 2003).

Similarly, it seems reasonable that geographic proximity of a university and their entrepreneurial actors (such as USOs) to a knowledge and technology intensive industry can be certainly a source of relevant knowledge and technological externalities. Indeed, USOs may constitutes a key mean for disseminating the newest knowledge and technologies from university to the local entrepreneurial context (Sternberg 2014; Campbell and Carayannis 2016). This follow closely the argument advocated by the theory of endogenous economic growth, for which growth and innovation have been partially related to the local academia by transferring technologies into developed innovations. Furthermore, as being possible sources of forthcoming knowledge and technologies transfers, they implicitly foster local economic development and innovation by attracting innovative firms to the local context (Funke and Niebuhr, 2005; Varga, 1999).

However, although their importance, the above arguments are not fully explored in the literature of the university entrepreneurship, leaving open some noteworthy knowledge gaps. Indeed, up to now, there are few studies that are directly dedicated in studying the effect of USOs on the local context. An effort in this sense has been made by the study of Iacobucci and Micozzi (2015), which investigated the direct 
(such as the number of spin-offs and their size in terms of sales and employees, the number of entrepreneurs involved) and indirect effects (such as the ability to form new networks to access finance and to improve sales and R\&D partnerships) of academic spin-offs on the local context in Italy. Also, Vincett (2010) analysed the economic impacts of academic spin-offs by estimating the lifetime effects of academic spin-off and compare the effects with all public direct and indirect funding. Nevertheless, the existing literature seems not to cover the potential technology and knowledge transfer effects of USOs in improving the innovation capabilities and outcomes of the local context. In this paper, we want to fill this gap by investigating whether USOs partially determine the innovation of regions. Additionally, the spinoff phenomenon in different European regions is likely to diverge from that one observed in successful high-tech clusters as Silicon Valley and Route 128 in the United Stated. Hence, this call to increase the evaluation of USOs impact to the local context in European regions.

This paper purposes to add some new evidence in this regard. To this end, the paper analyses a panel sample of 944 USOs located in 20 Italian administrative regions. Italy is one of the key European countries exposing a constant development of the USO phenomenon (Fini et al., 2011; Meoli and Vismara, 2016). Indeed, consistent with the last Netval report, at 31.12.2019 there are 1.373 research spinoffs in Italy. The paper aims to offer a prospective contribution to the knowledge - both theoretical and practical - about the role of the Entrepreneurial University, by means of USOs, in partially determine the innovation of local contexts thanks to the proactive role of knowledge and technology transfer. Also, the paper aims to boost appropriate policy actions dedicated to rise the regional development, contributing to the effective exploitation of innovation and promoting the socio-economic growth of the local areas.

\section{Theoretical background}

\subsection{The University knowledge and technology' effect on the local context}

The role of universities with their knowledge impacts are considered critical externalities of academic institutions on a local context (Florax and Folmer, 1992; Bleaney et al., 1992). Although the approaches of university' impacts do not diverge basically from the comparable outcomes of any others impact produced by public local institutions, the University knowledge effect is related to the specific mechanisms for which universities can impact on the socio-economic settings of a local area (Siegfried et al., 2007; Pellenbarg, 2005).

Knowledge effects are enabled through the so-called University technology transfers, which represents a potential and powerful direct outcome of the academic institution on the local economy. Namely, valuable ides from a technological point of view created in academic laboratories are transferred into innovative products or new production processes.

Further, an indirect effect of technology transfer emerges on regional socio-economic growth. Indeed, the entrepreneurial organizations may locate in the local area 
to take benefit of novel, economically valuable technologies created in academia. It is to note that University technology transfer is any practice by which basic R\&D research, knowledge and inventions transfer from an academic institution to the industry (Bania et al., 1992; Acs et al., 1999). The technology and knowledge may be moved from the universities throughout several mechanisms, such as collaboration in R\&D between University and industry, academic seminars, academic journal publications, business incubators, science parks, technology licensing and USO to commercialize valuable research' outcome and knowledge/technology developed at the academic institution (Lundberg, 2017).

\subsection{The impact of USOs on the innovation of regions}

In the current University model of the Triple Helix, the academic institution is called to take a leading role in the promotion and creation of innovation, inserting itself among the first proponents of the process aimed at disseminating innovation in the current knowledge-based society (Etzkowitz and Leydesdorff, 2017; Etzkowitz and Ranga, 2015). The progressive enrichment of the University' as a generator of opportunities for innovative forms of entrepreneurship - Entrepreneurial University has changed the socio-economic role of universities in many countries (Etzkowitz, 2004). On the other hand, the theoretical analysis and the experimental investigation about the mechanisms for which the University can fulfil the new task converge in signalling the creation of spin-off companies, a powerful tool for the commercialization of knowledge and technologies developed in the field of Higher Education (Wright, 2007; O'shea et al., 2005). Indeed, these types of firms provide a direct and leading contribution to the development of the socio-economic environment, especially in terms of innovative contribution (Perkmann et al., 2013; Martinelli et al., 2008). This statement is likely bearing in mind that a greater entrepreneurial orientation of the University could facilitate the absorption of the knowledge and technologies developed in the academia by the firms operating in the regional context, with a consequent attribution of economic-social value to the one that to the others (Di Gregorio and Shane, 2003; Lockett and Wright, 2005; Guerrero et al., 2015).

Emphasizing the impact of university research on the skills and innovation processes developed by firms (Audretsch et al., 2012; Leten et al., 2011; Johnstonm and Huggins, 2017), some studies have found that the USOs can effectively produce a spill-over of knowledge towards the business world. Nonetheless, this type of event tends to manifest itself as very localized and appears strongly bound to the requirement of geographical proximity between the University and the business environments. In the Italian context and in the context of the interaction between university and local industry, some problems emerge which strictly undermine the effectiveness of the transfer of knowledge, skills and technologies from research to entrepreneurship (Cardamone et al., 2015). The obstacles to this effort are primarily recognizable in a cultural environment poorly inclined to relationship and collaboration between academicians and entrepreneurs, with a lack of networks rooted and widespread between universities and industry (Link and Scott, 2005; Berbegal- 
Mirabent et al., 2015). In view of this emerging setting, it becomes critical to enhance the role of liaison fulfilled by USOs. These by acting as intermediaries for the dissemination of knowledge/technology generated by the University to potential users, such as companies and institutions (Cardamone et al., 2015; Bramwell and Wolfe, 2008), constitute a pool of qualified resources both for the effective economic development of regional context. Additionally, USOs have a part in updating the industrial production from traditional or low-tech sectors to high-tech sectors, as well as contributing to the transition towards the modern knowledge society (Rodríguez-Gulías et al., 2016). The development of innovation and diffusion of knowledge/technological know-how by USOs is also remarked by the Knowledge Spillover Theory of Entrepreneurship, an approach that explain the need to create new companies for the declination in economic term of knowledge/technology developed through university research (Carree et al., 2014; Audretsch and Lehmann, 2005).

According to the evidence emerging from previous empirical studies, a more intense and effective interaction between the University and the local industry - through USOs - positively influences the results achieved by both actors, both in terms of technology transfer (O'Shea et al., 2005; Landry et al., 2006), both in terms of economic/innovative performance (Acs and Plummer, 2005). In the theoretical literature, however, the impact produced by the activity of USOs on the regional socioeconomic environment has received evaluations and findings that are often premature and almost only partial (Vincett, 2010; Berggren and Lindholm-Dahlstrand, 2009; Benneworth and Charles, 2005). However, it is possible to rely on the classification proposed by Iacobucci and Micozzi (2015) and analyse the influence that USOs are potentially able to exert on regional socio-economic systems based on the following factors:

- Number of active spin-offs

- Performance in terms of growth achieved by them.

- Type and intensity of positive externalities produced on the local system.

In addition to the measurement criteria described above - associated with those that are generally defined as "direct" effects - it arises the role USOs play in the technological promotion and, therefore, in the emergence of new technology-driven clusters, although this constitutes an "indirect" effect only (Smith and Ho, 2006; Di Gregorio and Shane, 2003). This evidence is particularly true regarding socio-economic areas characterized by underdeveloped and not well-diffused innovation (Berggren and Lindholm-Dahlstrand, 2009), such as the Italian context and several European countries (mainly in the Mediterranean area).

In addition to the above arguments, it should be noted that USOs are knowledgebased firms and, generally, they are established by the University through patents and other forms of intellectual property (Lockett and Wright, 2005). The innovative potential of these types of firms, therefore, also depends on the possibility to 
commercialize the developed technology, guaranteed by the filing of patents $\mathrm{Mu}-$ nari et al., 2016). The latter, by providing protection and ensuring the economic appropriation of the invention advanced, are effective means to facilitate and optimize the diffusion of new knowledge and technologies within the socio-economic context of reference and, consequently, they can be validly enclosed among the most rational criteria to transfer the innovation to the local industry, partially determining the latent impact of USO's on the innovation of the regional context (Woo et al., 2015).

Research hypothesis: USOs have a positive effect in partially determining the innovation of regions where they are located

\section{Method}

\subsection{Sample and data}

In order to empirically validate the defined research hypothesis, information about USOs was collected from Netval database, which is incorporated in the project "Spin-off Italia" and founded in association with Netval, Università Politecnica delle Marche (Polytechnic University of Marche) and Scuola Superiore Sant'Anna - Istituto di Management (Saint Anna's Upper School - Management Institute). The Netval database comprises rationalized data about the full population of active spinoff firms in Italy. From the complete database, we collected only the USOs, i.e. 1,275 firms. Furthermore, additional data about the selected firms was gathered from Aida BdV database. The Aida BdV database is an Italian subsection of ORBIS database, which contains financial, biographical and merchandise historical data of about 700,000 Italian active firms. Precisely, financial data are offered by Honyvem, which gets and recovers all formal financial records placed in the Italian Chambers of Commerce. From the 1,275 USOs we omitted those firms for which information were not accessible in Aida BdV database for the time period selected. Thus, the final panel sample contains 944 Italian USOs, covering a period from 2009 to 2019. Data about the regional innovation of the all-20 Italian administrative regions (i.e. Valle d'Aosta, Trentino-Alto Adige, Lombardy, Veneto, Emilia-Romagna, Marche, Abruzzi, Molise, Apulia, Calabria, Sardinia, Piedmont, Friuli-Venezia Giulia, Liguria, Tuscany, Umbria, Lazio, Campania, Basilicata, Sicily) was gathered by obtaining information from the records collected by the Organization for Economic Co-operation and Development (OECD). In addition, information concerning the regional Venture Capital \& Private Equity industry was collected from the yearly statements of Private Equity Monitor - PEM ${ }^{\circledR}$. 


\subsection{Variable definition}

\subsubsection{Dependent variables}

With the aim to measure the innovation of Italian administrative regions we used two variables. First, we used the number of patent applications from the analysed regions (REGION PATENT). Indeed, the literature claims that patents offer a consistent measure of the innovative spillover of a region (innovation output), embodying a fundamental and dominant proxy of regional creation of knowledge and technology (Acs et al., 2002).

Second, we used the total volume of regional expenditure in R\&D (REGION R\&D), which is argued to be a key measure of regional innovation (Link and Siegel 2005), constituting an important innovation input.

\subsubsection{Independent variables}

To predict the latent impact of USOs on the innovation of regions it was used the number (count) of USOs from each University (NUMBER USO). Indeed, the count of USOs is a proper measure to assess the impact of spill-over effect on regional environment (Iacobuzzi and Micozzi 2015). Also, a dummy variable about the patent activity (number of patents on each year) of USOs has been used (USO PATENT). Of course, patents are key results of firms' innovation, embodying an entrepreneurial outcome within the innovative actions of the University' firms. Furthermore, patenting activity is applied usually to assess the innovation outcome of USOs (Rodríguez-Gulías et al. 2016).

\subsubsection{Control variables}

First, we controlled for one of the key inputs in developing regional innovation, i.e. the human capitals in $R \& D$ activities, which should have a relation with regional patents. For this variable it was used the number of $R \& D$ workers in the region over total amount of workers (R\&D HUMAN CAPITAL).

Second, since the innovation of regions is related to the knowledge aptitudes and know-how of the individuals existing in the local area, it was used the ratio of adult people (age 16+) with higher education in each region (HIGH EDUC).

Third, we controlled for the extent of Venture Capital (VC) and Private Equity (PE) industry by means of the total amount of early agreements for $\mathrm{VC}$ and $\mathrm{PE}$ in each region (VC/PE).

Fourth, we controlled for the natural logarithm of the number of innovative companies in each region (INNOV FIRMS). Finally, we controlled for the pro-capital GDP in each region (GDP). 


\subsection{Analytical approach}

The following regional innovation functions has been defined, and it is consistent for time effects:

$$
\begin{aligned}
& \text { REGION PATENT } i t=f\left(\beta_{0}+\beta_{1} \text { NUMBER USO }_{i}+\right. \\
& +\beta_{2} \text { R\&D HUMAN CAPITAL } L_{i t}+\beta_{3} \text { HIGH EDUC } i t+\beta_{4} \mathrm{VC} / \mathrm{PE}_{i t}+
\end{aligned}
$$

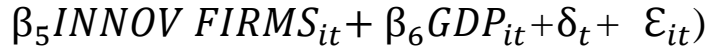

$$
\begin{aligned}
& \text { REGIONAL R\&D } D_{i t}=f\left(\beta_{0}+\beta_{1} \text { NUMBER USO }_{i}+\right. \\
& +\beta_{2} R \& D \text { HUMAN CAPITAL } L_{i t}+\beta_{3} \text { HIGH EDUC } i t+\beta_{4} \mathrm{VC} / \mathrm{PE}_{i t}+ \\
& \left.\beta_{5} \text { INNOV FIRMS }_{i t}+\beta_{6} G D P_{i t}+\delta_{t}+\varepsilon_{i t}\right) \\
& \text { REGION PATENT } i t=f\left(\beta_{0}+\beta_{1} \text { USO PATENT }_{i}+\right. \\
& +\beta_{2} R \& D \text { HUMAN CAPITAL } L_{i t}+\beta_{3} \text { HIGH EDUC } i t+\beta_{4} \mathrm{VC} / \mathrm{PE}_{i t}+
\end{aligned}
$$

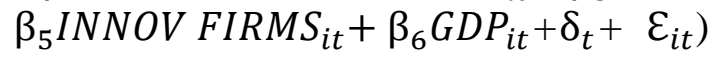

$$
\begin{aligned}
& \text { REGIONAL R\&D } D_{i t}=f\left(\beta_{0}+\beta_{1} \text { NUSO PATENT }_{i}+\right. \\
& +\beta_{2} R \& D \text { HUMAN CAPITAL } i t+\beta_{3} \text { HIGHEDUC } C_{i t}+\beta_{4} \mathrm{VC} / \mathrm{PE}_{i t}+
\end{aligned}
$$

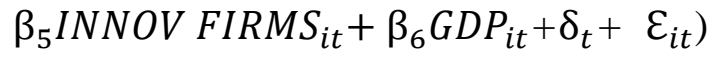

Where $i$ indexes universities and $t$ indexes years. In addition, $\approx \mathrm{t}$ is the time effect and $\varepsilon_{\text {it }}$ is the error term.

A regression models' estimation for panel data has been used to estimate the functions above, using the xtreg command of the statistical software STATA. In particular, the regression estimations have been performed by means of a fixed-effects model (by using the within regression estimator).

\section{Results}

\subsection{Descriptive statistics}

Table 1 shows the descriptive statistics of variables used in the study. Concerning the first measure of regional innovation used - the amount of patent applications (innovation output) - the sample shows an average of 414.88 patents, with a medium-high heterogeneity in the sample (S.D. $=408.43)$. This result remarks a good distribution of the innovative outputs in the Italian regions, though its extent varies considerably between regions. The second measure of regional innovation used the total amount of regional expenditure in R\&D (innovation input) - shows an average in the sample of $1,591.64 €$, while the dispersion in the sample is quite high (S.D. $=1,281.37)$.

The descriptive statistics suggest that it occurs a relevant heterogeneity in the analysed Italian regions in term of innovation, advocating that the regional areas are reasonably diversified in Italy. 
Regarding to the first fundamental explanatory variable, the amount of USOs from each University, the sample reveals an average of about 28 USOs per academic institution. However, the amount of USOs is affected by a medium-high dispersion in the sample (S.D. = 16.07). The result suggests that USO is a disseminated phenomenon in the Italian context, with a relevant latent influence on the regional area in which it is placed, although this distribution considerably varies between regions. This may generate concerns also regarding the effect' power of USOs on the regional innovation, rising differences in innovation efforts between regions.

Additionally, about the second main explanatory variable, the patenting activity of USOs, the sample denotes an average of $4 \%$ of USOs with patents. This result remarks the small orientation to innovative by the analysed USOs. However, the evidence could suggest only a small aptitude to protect the innovation produced rather an underperformance in innovation outcomes.

Table 1: Descriptive statistics

\begin{tabular}{|c|c|c|c|c|c|}
\hline & Obs. & Mean & Std. Dev. & Min. & Max. \\
\hline $\begin{array}{c}\text { REGION } \\
\text { PATENT }\end{array}$ & 7,552 & 414.8825 & 408.4335 & 0.3500 & 1509.0500 \\
\hline REGION R\&D & 8,496 & $1,591.6440$ & $1,281.3710$ & 12 & $4,625.4520$ \\
\hline $\begin{array}{c}\text { NUMBER } \\
\text { USO }\end{array}$ & 9,440 & 27.7341 & 16.0609 & 1 & 70 \\
\hline USO PATENT & 9,440 & 0.0414 & 0.1992 & 0 & 1 \\
\hline $\begin{array}{c}\text { R\&D HUMAN } \\
\text { CAPITAL }\end{array}$ & 7,539 & 6.1062 & 15.7358 & 0.5400 & 112.2400 \\
\hline HIGH EDUC & 9,440 & 17.0699 & 2.9603 & 11.1000 & 36.1000 \\
\hline VC/PE & 9,440 & 116.0561 & 138.3637 & 0 & 464 \\
\hline $\begin{array}{c}\text { INNOV } \\
\text { FIRMS }\end{array}$ & 9,440 & 8.4822 & 0.9382 & 4.6821 & 9.9512 \\
\hline GDP & 9,440 & $27,783.2900$ & $5,728.0110$ & 15,800 & 37,250 \\
\hline
\end{tabular}


With the aim to have a better detailed understanding about the dynamics of the key variables used, Figure 1 reports the amount of USOs placed in each region. The results show that the distribution of USOs between regions is quite heterogenous. In detail, the regions showing the highest amount of USOs therein placed are in the Centre-North of Italy, particularly in Lombardy, Piedmont and Tuscany, while the regions characterized by the lowest amount of USOs are in the South, namely Sardinia, Molise and Calabria. However, a lowest amount of USOs is detected also for two regions of the North, namely Valle d'Aosta and Trentino-Alto Adige (in this case the reasons are related to the small size of these two regions).

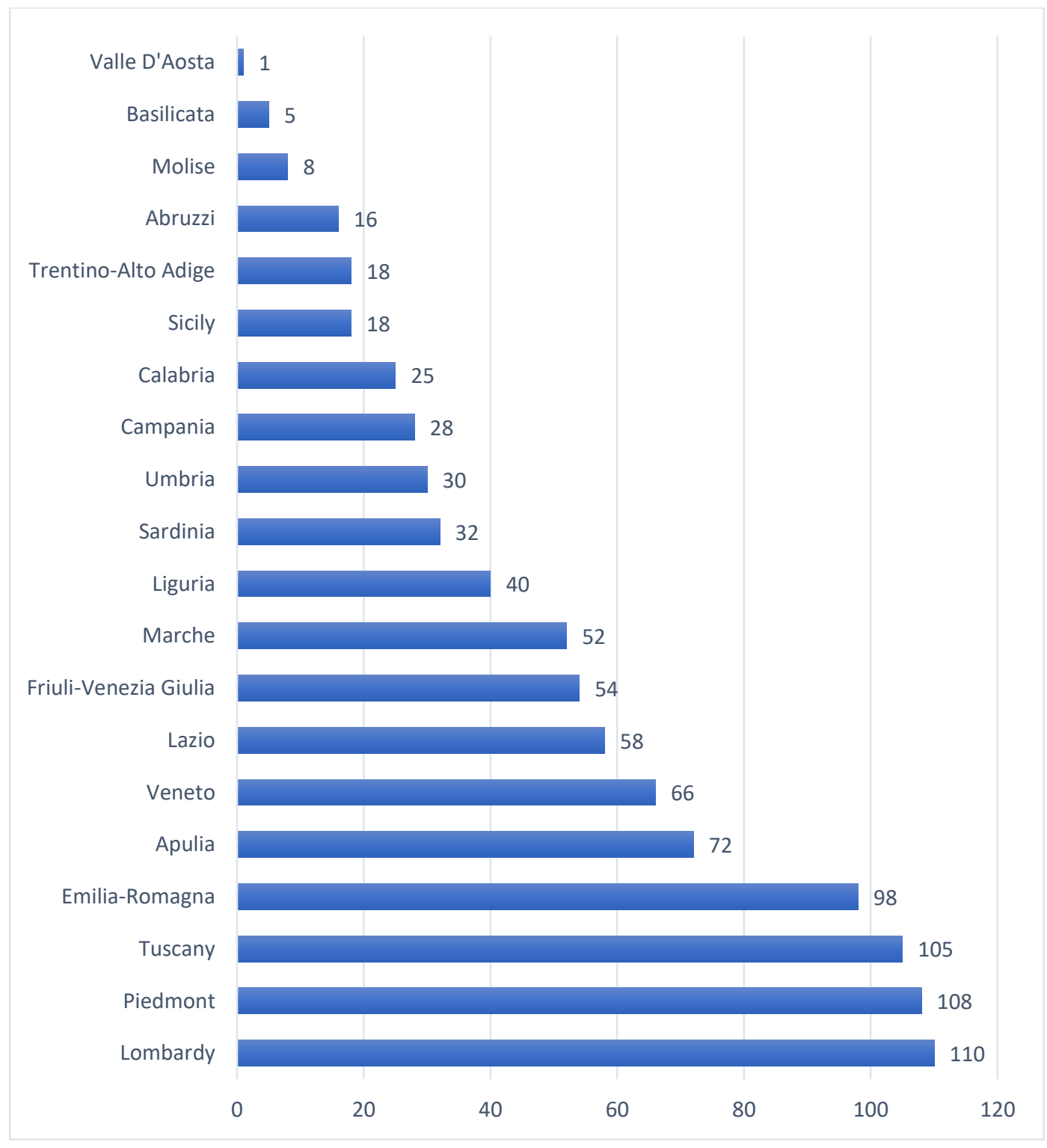

Figure 1: Amount of USOs placed in each Italian region 
Figure 2 shows the amount of USOs with patenting activities by region. The results show that the distribution of USOs patents between regions mostly denotes a similarity with the distribution of the amount of USOs placed in each Italian region. The regions reporting the highest amount of USOs with patent activity are in the CentreNorth of Italy, particularly in Lombardy, Tuscany and Emilia-Romagna; while the regions characterized by USOs with less patents are located mainly in the South of Italy: Abruzzi, Molise, Basilicata and Valle D'Aosta.

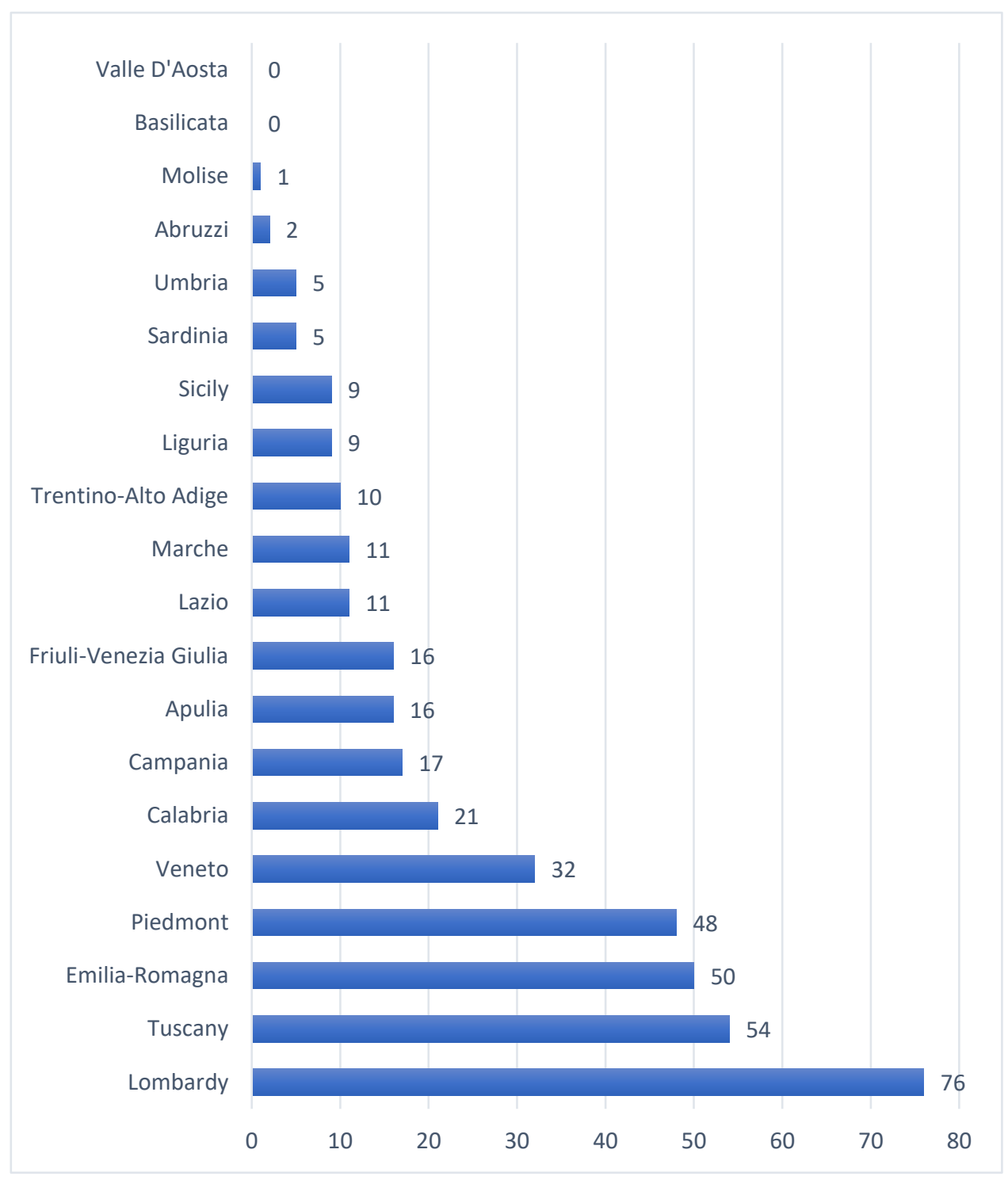

Figure 2: Amount of USOs with patents by Italian regions 
Furthermore, the lack of high significant correlations among the key explicative variables (Table 2) suggests that multicollinearity is not a main concern in this study.

Table 2: Correlations

\begin{tabular}{|c|c|c|c|c|c|c|c|c|c|c|}
\hline & & 1 & 2 & 3 & 4 & 5 & 6 & 7 & 8 & 9 \\
\hline 1 & \begin{tabular}{|l|} 
REGION \\
PATENT \\
\end{tabular} & 1.0000 & & & & & & & & \\
\hline 2 & $\begin{array}{c}\text { REGION } \\
\text { R\&D }\end{array}$ & $0.8356^{*}$ & 1.0000 & & & & & & & \\
\hline 3 & $\begin{array}{c}\text { NUMBER } \\
\text { USO }\end{array}$ & $0.1039^{*}$ & $0.0662 *$ & 1.0000 & & & & & & \\
\hline 4 & \begin{tabular}{|c|} 
USO \\
PATENT
\end{tabular} & $0.0514 *$ & $0.0515 *$ & $0.0216^{*}$ & 1.0000 & & & & & \\
\hline 5 & $\begin{array}{c}\text { R\&D } \\
\text { HUMAN } \\
\text { CAPITAL } \\
\end{array}$ & $0.1611^{*}$ & 0.0205 & $0.0279 *$ & $-0.0368 *$ & 1.0000 & & & & \\
\hline 6 & $\begin{array}{l}\text { HIGH } \\
\text { EDUC }\end{array}$ & $-0.1306^{*}$ & $0.1376^{*}$ & $-0.1813 *$ & 0.0114 & $-0.2657 *$ & 1.0000 & & & \\
\hline 7 & $\begin{array}{l}\text { INNOV } \\
\text { FIRMS }\end{array}$ & $0.8323^{*}$ & $0.8261^{*}$ & $0.1481^{*}$ & $0.0559^{*}$ & $0.1200 *$ & $-0.0782 *$ & 1.0000 & & \\
\hline 8 & $\mathrm{VC} / \mathrm{PE}$ & $0.9586^{*}$ & $0.8697 *$ & 0.0034 & 0.0587* & $0.0922 *$ & $-0.0249 *$ & $0.7813^{*}$ & 1.0000 & \\
\hline 9 & GDP & $0.6760^{*}$ & $0.6799^{*}$ & $0.1435^{*}$ & $0.0328^{*}$ & $0.0294 *$ & $0.3765^{*}$ & $0.6354^{*}$ & $0.6502 *$ & 1.0000 \\
\hline
\end{tabular}

$* \mathrm{p}<0.05$ (all two-tailed tests).

\subsection{Estimation of the defined regression models}

Table 3 reports the results of the Model (1) and Model (2) with the aim to evaluate the effect of USOs, in term of amount (count) of USOs from each University, on regional innovation.

In the Model (1), which predicts the effect of the number of USOs from a given University on the amount of patent applications at regional level, the estimated coefficient on the variable NUMBER USO is positive and statistically significant (column ii, coeff. $=0.5476, p<0.001)$. In the Model (2), which predicts the effect of the number of USOs from a given University on the regional expenditure in R\&D, the estimated coefficient on the variable NUMBER USO is positive but not statistically significant.

This evidence provides partially support to the defined research hypothesis, suggesting that the presence of USOs contribute to determine the innovation of regions in which they are placed only in term of innovation output, but not in term of innovation input. 
Table 3: Estimation of the defined regression models predicting the effect of USOs, in term of amount (count) of USOs from each University, on regional innovation

\begin{tabular}{|c|c|c|c|c|}
\hline \multirow[t]{2}{*}{ Dependent variable: } & \multicolumn{2}{|c|}{$\begin{array}{c}\text { Model 1 } \\
\text { REGION PATENT }\end{array}$} & \multicolumn{2}{|c|}{$\begin{array}{c}\text { Model } 2 \\
\text { REGION R\&D }\end{array}$} \\
\hline & (i) & (ii) & (iii) & (iv) \\
\hline \multicolumn{5}{|l|}{ Main effect } \\
\hline NUMBER USO & & $\begin{array}{c}0.5476 * * * \\
(0.1028)\end{array}$ & & $\begin{array}{c}1.6506 \\
(1.2797) \\
\end{array}$ \\
\hline \multicolumn{5}{|l|}{ Control variables } \\
\hline $\begin{array}{l}\text { R\&D HUMAN } \\
\text { CAPITAL }\end{array}$ & $\begin{array}{c}0.5329 * * * \\
(0.0536)\end{array}$ & $\begin{array}{c}0.5547 * * * \\
(0.0533)\end{array}$ & $\begin{array}{c}-3.5817 * * * \\
(0.2457)\end{array}$ & $\begin{array}{c}-3.5848 * * * \\
(0.2459)\end{array}$ \\
\hline HIGH EDUC & $\begin{array}{c}-25.5163 * * * \\
(1.1976) \\
\end{array}$ & $\begin{array}{c}-24.6635 * * * \\
(1.2281) \\
\end{array}$ & $\begin{array}{c}61.9847 * * * \\
(3.0023)\end{array}$ & $\begin{array}{c}62.0698 * * * \\
(2.9953)\end{array}$ \\
\hline INNOV FIRMS & $\begin{array}{c}51.2184 * * * \\
(4.1011)\end{array}$ & $\begin{array}{c}49.2491 * * * \\
(4.3458)\end{array}$ & $\begin{array}{c}496.9692 * * * \\
(30.1672)\end{array}$ & $\begin{array}{c}487.0723 * * * \\
(31.2164)\end{array}$ \\
\hline VC/PE & $\begin{array}{c}2.0823 * * * \\
(0.0210)\end{array}$ & $\begin{array}{c}2.1087 * * * \\
(0.0228)\end{array}$ & $\begin{array}{c}4.7924 * * * \\
(0.1698)\end{array}$ & $\begin{array}{c}4.8525 * * * \\
(0.1878)\end{array}$ \\
\hline GDP & $\begin{array}{c}0.01459 * * * \\
(0.0005)\end{array}$ & $\begin{array}{c}0.0140 * * * \\
(0.0006)\end{array}$ & $\begin{array}{c}0.0216 * * * \\
(0.0031)\end{array}$ & $\begin{array}{c}0.0213 * * * \\
(0.0031)\end{array}$ \\
\hline Number of obs & 6,595 & 6,595 & 7,539 & 7,539 \\
\hline \multicolumn{5}{|l|}{ R-sq: } \\
\hline within & 0.2563 & 0.2557 & 0.4896 & 0.4895 \\
\hline between & 0.9825 & 0.9832 & 0.8456 & 0.8461 \\
\hline overall & 0.9590 & 0.9596 & 0.8377 & 0.8382 \\
\hline Wald $\operatorname{chi}^{2}(6)$ & $271549.0400 * * *$ & $265344.8200 * * *$ & $33463.4400 * * *$ & $34038.9200 * * *$ \\
\hline
\end{tabular}

Notes: Robust standard errors in parenthesis. ***p $<0.001 ; * * \mathrm{p}<0.01 ; * \mathrm{p}<0.05$.

Table 4 reports the results of the Model (3) and Model (4) with the aim to evaluate the effect of USOs, in term of patent activity, on regional innovation. In the Model (3), which predicts the effect of the USOs' patents on the number of patent applications in the regions, the estimated coefficient on the variable USO PATENT is positive and statistically significant (column ii, coeff. $=8.7066, \mathrm{p}<0.001$ ). In the Model (4), which predicts the effect of the USOs' patents on the regional expenditure in R\&D, the estimated coefficient on the variable USO PATENT is positive but not statistically significant.

The results from the estimated models suggest that the innovation outcome of USOs partially contribute to determine the innovation of regions in which they are placed. Indeed, also in this case, the evidence remarks that USOs' patents have a superior impact on innovation output rather than on innovation input at regional level. Hence, in general the results partially support the defined research hypothesis. 
Table 4: Estimation of the defined regression models predicting the effect of USOs, in term of patent activity, on regional innovation

\begin{tabular}{|c|c|c|c|c|}
\hline \multirow[t]{2}{*}{ Dependent variable: } & \multicolumn{2}{|c|}{$\begin{array}{c}\text { Model 3 } \\
\text { REGION PATENT }\end{array}$} & \multicolumn{2}{|c|}{$\begin{array}{c}\text { Model } 4 \\
\text { REGION R\&D }\end{array}$} \\
\hline & (i) & (ii) & (iii) & (iv) \\
\hline \multicolumn{5}{|l|}{ Main effect } \\
\hline USO PATENT & & $\begin{array}{l}8.7066^{*} \\
(4.4493) \\
\end{array}$ & & $\begin{array}{c}8.0431 \\
(9.7719) \\
\end{array}$ \\
\hline \multicolumn{5}{|l|}{ Control variables } \\
\hline $\begin{array}{l}\text { R\&D HUMAN } \\
\text { CAPITAL }\end{array}$ & $\begin{array}{c}0.5329 * * * \\
(0.0536)\end{array}$ & $\begin{array}{c}0.5368 * * * \\
(0.0537)\end{array}$ & $\begin{array}{c}-3.5817 * * * \\
(0.2457)\end{array}$ & $\begin{array}{c}-3.5787 * * * \\
(0.2459)\end{array}$ \\
\hline HIGH EDUC & $\begin{array}{c}-25.5163 * * * \\
(1.1976)\end{array}$ & $\begin{array}{l}-25.5297 * * * \\
(1.1973)\end{array}$ & $\begin{array}{c}61.9847 * * * \\
(3.0023)\end{array}$ & $\begin{array}{c}61.9667 * * * \\
(3.0018)\end{array}$ \\
\hline INNOV FIRMS & $\begin{array}{c}51.2184 * * * \\
(4.1011)\end{array}$ & $\begin{array}{c}51.1767 * * * \\
(4.1017)\end{array}$ & $\begin{array}{c}496.9692 * * * \\
(30.1672)\end{array}$ & $\begin{array}{c}496.9356 * * * \\
(30.1733)\end{array}$ \\
\hline $\mathrm{VC} / \mathrm{PE}$ & $\begin{array}{c}2.0823 * * * \\
(0.0210)\end{array}$ & $\begin{array}{c}2.0817 * * * \\
(0.0210)\end{array}$ & $\begin{array}{c}4.7924 * * * \\
(0.1698)\end{array}$ & $\begin{array}{c}4.7919 * * * \\
(0.1699)\end{array}$ \\
\hline GDP & $\begin{array}{c}0.01459 * * * \\
(0.0005)\end{array}$ & $\begin{array}{c}0.0146 * * * \\
(0.0005)\end{array}$ & $\begin{array}{c}0.0216 * * * \\
(0.0031)\end{array}$ & $\begin{array}{c}0.0216 * * * \\
(0.0031)\end{array}$ \\
\hline Number of obs & 6,595 & 6,595 & 7,539 & 7,539 \\
\hline \multicolumn{5}{|l|}{ R-sq: } \\
\hline within & 0.2563 & 0.2565 & 0.4896 & 0.4897 \\
\hline between & 0.9825 & 0.9826 & 0.8456 & 0.8456 \\
\hline overall & 0.9590 & 0.9591 & 0.8377 & 0.8377 \\
\hline Wald chi $^{2}(6)$ & $271549.0400 * * *$ & $270703.5200 * * *$ & $33463.4400 * * *$ & $33474.8700 * * *$ \\
\hline
\end{tabular}

Notes: Robust standard errors in parenthesis. ***p $<0.001 ; * * \mathrm{p}<0.01 ; * \mathrm{p}<0.05$.

\section{Conclusion}

\subsection{Result discussion}

The paper aimed to analyse the effect of USOs in partially determine the innovation of regional contexts in which they are placed. This study provides new insights, although only partial, about the understanding of the dynamics affecting innovativeness in the regions. The findings from a panel sample of 944 Italian USOs placed in 20 Italian administrative regions remark the positive effect of USOs, both in term of amount (count) of USOs from each academic institution and in term USOs' patents activity, on the level of regional innovation measured as amount of patent applications at regional level.

This evidence suggests that knowledge and technologies transfer from the University by USOs may produce a relevant impact in the regional area, rising its innovative capabilities especially in term of innovation output, i.e., patents, operating as key intermediate in the innovative advance of regions.

Nevertheless, concerning the effect of USOs, both in term of amount (count) of 
USOs from each academic institution and in term USOs' patents activity, on the regional expenditure in $R \& D$, the findings remark a weak effect of USOs in determine the basic regional elements of innovation, i.e. their innovation input measured by the R\&D efforts at regional level. Though the innovation outcome of the university ventures provides greater benefits to the local area (which stems from the knowledge/technology generated in academia), they will be yet inadequate to rise the innovation input of the regions. This result remarks that the impact of USOs to the innovation of regions, although considerably, is yet not-fully exploited. Indeed, the regional setting will take advantage from the innovative output and entrepreneurial activity of USOs, which conversely forms the input to improve the basic elements in the regional context that raise the innovation efforts of the same, both in term of innovation inputs and, then, translating them in innovation outputs (consistently with the Knowledge Spillover Theory of Entrepreneurship). However, the emerging findings from our sample seems to reveal that the Italian USOs have not advanced an appropriate level of innovative and entrepreneurial activity to aid the regional area in the development of the fundamental milieu for the exploitation of its innovative copiabilities. On the other hand, the lowest impact of USOs on innovation input of regions may be related to the weak capability of the socio-economic areas to capture and exploit the knowledge and technology spillover from USOs. However, generally USOs seems to affect the innovation of regions in Italy, although their effects are only partial and not-fully integrated in the knowledge and technology spillover process.

\subsection{Implications of the study}

The paper provides suitable theoretical and managerial/policy implications. From a theoretical point of view, the study provides news insights in the literature about the function of knowledge and technology transfer process from the academia in rise the innovation efforts of local areas. Chiefly, the paper contributes to supporting the theoretical arguments associated to the valuable innovative effect and potential knowledge spillovers from University. In this regard, the study confirms the effective role, although partial, of USOs in stimulating a confident background for the rise of innovation in regions where they are placed.

From a managerial/policy point of view, the emerging role of USOs in partially determine the innovation of regions calls policy makers to develop action and dedicated programs to improve strong and mutual partnership among every part of the local area involved in the knowledge/technology spillover process, from the University to the industry. This is especially important for those regions missing a strong innovative and entrepreneurial ecosystem (the regions of the South for the Italian context) that demand a resilient and integrated agenda to increase their innovative potentials and knowledge/technology exploitation of their university and industry. In this regard, a possible and rational recommendation for policy makers and practitioners is to employ a more selective approach in the supporting programs, rather the traditional and well-diffused bottom-up approach, aimed at boosting the 
most effective and promising USOs in a definite technological and knowledge domain.

\subsection{Limitations}

Nevertheless, the paper is not free from limitations, which leaves room for future research. The empirical study is based only on some determinants of innovation of the local area and only on some impacts exerted by USOs. Moreover, the models developed can be considered only as basic cognitive elements to help the improvement of the existing knowledge about the effects of USOs in regions they are located, as well as serving as inputs for a more system conceptual and empirical model on the topic. Further studies may include additional variables measuring regional innovation through proxies expressing the existence of high-tech start-ups and new technology-based firms (NTBF) in the local area - which constitute basic agents in the generation of on innovation-based links between university and industry - as well as Science Parks and technology clusters.

\section{References}

[1] Acs, Z. J., Anselin, L. and Varga, A. (2002). "Patents and innovation counts as measures of regional production of new knowledge", Research policy, vol. 31, no. 7, 2002, pp. 1069-1085.

[2] Acs, Z. J., Fitzroy, F. R. and Smith, I. (1999). "High technology employment, wages and university R\&D spillovers: Evidence from US cities", Economics of innovation and new technology, vol. 8, no. 1-2, 1999, pp. 57-78.

[3] Acs, Z. J. and Plummer, L. A. (2005). "Penetrating the "knowledge filter"in regional economies", The Annals of Regional Science, vol. 39, no. 3, 2005, pp. 439-456.

[4] Audretsch, D. B. and Keilbach, M. (2008). "Resolving the knowledge paradox: Knowledge-spillover entrepreneurship and economic growth", Research Policy, vol. 37, no. 10, 2008, pp. 1697-1705.

[5] Audretsch, D. B. and Lehmann, E. E. (2005). "Does the knowledge spillover theory of entrepreneurship hold for regions?", Research Policy, vol. 34, no. 8, 2005, pp. 1191-1202.

[6] Audretsch, D. B., Hülsbeck, M. and Lehmann, E. E. (2012). "Regional competitiveness, university spillovers, and entrepreneurial activity", Small Business Economics, vol. 39, no. 3, 2012, pp. 587-601.

[7] Bania, N., Calkins, L. N. and Dalenberg, D. R. (1992). "The effects of regional science and technology policy on the geographic distribution of industrial R\&D laboratories", Journal of Regional Science, vol. 32, no. 2, 1992, pp. 209228.

[8] Benneworth, P. and Charles, D. (2005). "University spin-off policies and economic development in less successful regions: learning from two decades of policy practice", European Planning Studies, vol. 13, no. 4, 2005, pp. 537-557. 
[9] Berbegal-Mirabent, J., Ribeiro-Soriano, D. E. and García, J. L. S. (2015). “Can a magic recipe foster university spin-off creation?", Journal of Business Research, vol. 68, no. 11, 2015, pp. 2272-2278.

[10] Berggren, E. and Lindholm Dahlstrand, А. (2009).

"Creating an entrepreneurial region: Two waves of academic spin-offs from Halmstad University”, European Planning Studies, vol. 17, no. 8, 2009, pp. 1171-1189.

[11] Bleaney, M. F., Binks, M. R., Greenaway, D., Reed, G. V. and Whynes, D. K. (1992). "What does a university add to its local economy?", Applied economics, vol. 24, no. 3, 1992, pp. 305-311.

[12] Bramwell, A. and Wolfe, D. A. (2008). "Universities and regional economic development: The entrepreneurial University of Waterloo", Research policy, vol. 37, no. 8, 2008, pp. 1175-1187.

[13] Campbell, D. F. and Carayannis, E. G. (2016). "The academic firm: a new design and redesign proposition for entrepreneurship in innovation-driven knowledge economy", Journal of Innovation and Entrepreneurship, vol. 5, no. 1, 2016, pp. 12.

[14] Cardamone, P., Pupo, V. and Ricotta, F. (2015). "University Technology Transfer and Manufacturing Innovation: The Case of Italy", Review of Policy Research, vol 32, no. 3, 2015, pp. 297-322.

[15] Carree, M., Della Malva, A. and Santarelli, E. (2014). "The contribution of universities to growth: Empirical evidence for Italy", The Journal of Technology Transfer, vol. 39, no. 3, 2014, pp. 393-414.

[16] Di Gregorio, D. and Shane, S. (2003). "Why do some universities generate more start-ups than others?", Research policy, vol. 32, no. 2, 2003, pp. 209227.

[17] Etzkowitz, H. (2004). "The evolution of the entrepreneurial university", International Journal of Technology and Globalisation, vol. 1, no. 1, 2004, pp. 6477.

[18] Etzkowitz, H. and Ranga, M. (2015). "Triple Helix systems: an analytical framework for innovation policy and practice in the Knowledge Society", Entrepreneurship and Knowledge Exchange, Routledge, 2015, pp. 117-158.

[19] Fini, R., Fu, K., Mathisen, M. T., Rasmussen, E. and Wright, M. (2017). "Institutional determinants of university spin-off quantity and quality: a longitudinal, multilevel, cross-country study", Small Business Economics, vol. 48, no. 2, 2017, pp. 361-391.

[20] Fini, R., Grimaldi, R., Santoni, S. and Sobrero, M. (2011). "Complements or substitutes? The role of universities and local context in supporting the creation of academic spin-offs", Research Policy, vol. 40, no. 8, 2011, pp. 1113-1127.

[21] Florax, R. and Folmer, H. (1992). "Knowledge impacts of universities on industry an aggregate simultaneous investment model”, Journal of Regional Science, vol. 32, no. 4, 1992, pp. 437-466. 
[22] Friedman, J. and Silberman, J. (2003). "University technology transfer: do incentives, management, and location matter?", The Journal of Technology Transfer, vol. 28, no. 1, 2003, pp. 17-30.

[23] Funke, M. and Niebuhr, A. (2005). "Regional geographic research and development spillovers and economic growth: evidence from West Germany", Regional Studies, vol. 39, no. 1, 2005, pp. 143-153.

[24] Guerrero, M. and Urbano, D. (2012). "The development of an entrepreneurial university", The journal of technology transfer, vol. 37, no. 1, 2012, pp. 43-74.

[25] Guerrero, M., Cunningham, J. A. and Urbano, D. (2015). "Economic impact of entrepreneurial universities' activities: An exploratory study of the United Kingdom", Research Policy, vol. 44, no. 3, 2015, pp. 748-764.

[26] Iacobucci, D. and Micozzi, A. (2015). "How to evaluate the impact of academic spin-offs on local development: an empirical analysis of the Italian case", The Journal of Technology Transfer, vol. 40, no. 3, 2015, pp. 434-452.

[27] Johnston, A. and Huggins, R. (2017). "University-industry links and the determinants of their spatial scope: A study of the knowledge intensive business services sector", Papers in Regional Science, vol. 96, no. 2, 2017, pp. 247-260.

[28] Kenney, M. and Patton, D. (2011). "Does inventor ownership encourage university research-derived entrepreneurship? A six university comparison", Research Policy, vol. 40, no. 8, 2011, pp. 1100-1112.

[29] Landry, R., Amara, N. and Rherrad, I. (2006). "Why are some university researchers more likely to create spin-offs than others? Evidence from Canadian universities", Research Policy, vol. 35, no. 10, 2006, pp. 1599-1615.

[30] Lazzeri, F. and Piccaluga, A. (2012). "Le imprese spin-off della ricerca pubblica: convinzioni, realtà e prospettive future", Economia e società regionale, vol. 1, 2012, pp. 43-65.

[31] Leten, B., Landoni, P. and Van Looy, B. (2011). "Developing technology in the vicinity of science: do firms benefit? An overview and empirical assessment on the level of Italian provinces", Science and Innovation Policy for the New Knowledge Economy, PRIME Series on Research and Innovation Policy in Europe, 2011, pp. 106-133.

[32] Leydesdorff, L., Etzkowitz, H., Ivanova, I. and Meyer, M. (2017).

The measurement of synergy in innovation systems: Redundancy generation in a triple helix of university-industry-government relations, Springer handbook of science and technology indicators, Heidelberg, Springer, 2017.

[33] Link, A. N. and Scott, J. T. (2005). "Opening the ivory tower's door: An analysis of the determinants of the formation of US university spin-off companies", Research Policy, vol. 34, no. 7, 2005, pp. 1106-1112.

[34] Link, A. N. and Siegel, D. S. (2005). "University-based technology initiatives: Quantitative and qualitative evidence", Research Policy, vol. 34, no. 3, 2005, pp. 253-257.

[35] Lockett, A. and Wright, M. (2005). "Resources, capabilities, risk capital and the creation of university spin-out companies", Research policy, vol. 34, no. 7, 2005, pp. 1043-1057. 
[36] Lundberg, J. (2017). "Does academic research affect local growth? Empirical evidence based on Swedish data", Regional Studies, vol. 51, no. 4, 2017, pp. 586-601.

[37] Martinelli, A., Meyer, M. and Von, N. (2008). Tunzelmann, "Becoming an entrepreneurial university? A case study of knowledge exchange relationships and faculty attitudes in a medium-sized, research-oriented university", The Journal of Technology Transfer, vol. 33, no. 3, 2008, pp. 259-283.

[38] Mathisen, M. T. and Rasmussen, E. (2019). "The development, growth, and performance of university spin-offs: a critical review", The Journal of Technology Transfer, 2019, pp. 1-48.

[39] Meoli, M. and Vismara, S. (2016). "University support and the creation of technology and non-technology academic spin-offs", Small Business Economics, vol. 47, no. 2, 2016, pp. 345-362.

[40] Miranda, F. J., Chamorro, A. and Rubio, S. (2018). "Re-thinking university spin-off: a critical literature review and a research agenda", The Journal of Technology Transfer, vol. 43, no. 4, 2018, pp. 1007-1038.

[41] Mueller, P. (2006). "Exploring the knowledge filter: How entrepreneurship and university-industry relationships drive economic growth", Research policy, vol. 35, no. 10, 2006, pp. 1499-1508.

[42] Munari, F., Rasmussen, E., Toschi, L. and Villani, E. (2016). "Determinants of the university technology transfer policy-mix: A cross-national analysis of gap-funding instruments", The Journal of Technology Transfer, vol. 41, no. 6, 2016, pp. 1377-1405.

[43] O'shea, R. P., Allen, T. J., Chevalier, A. and Roche, F. (2005). "Entrepreneurial orientation, technology transfer and spinoff performance of US universities", Research policy, vol. 34, no. 7, 2005, pp. 994-1009.

[44] Pellenbarg, P. H. (2005). "How to calculate the impact of a university on the regional economy A case study of the University of Groningen, the Netherlands", in University of Groningen, Conference on Knowledge and Regional Economic Development, Barcelona, 2005.

[45] Perkmann, M., Tartari, V., McKelvey, M., Autio, E., Broström, A., D’Este, P. and Krabel, S. (2013). "Academic engagement and commercialisation: A review of the literature on university-industry relations", Research policy, vol. 42, no. 2, 2013, pp. 423-442.

[46] Rodríguez-Gulías, M. J., Rodeiro-Pazos, D. and Fernández-López, S. (2016). "The regional effect on the innovative performance of university spin-offs: a multilevel approach", Journal of the Knowledge Economy, vol. 7, no. 4, 2016, pp. 869-889.

[47] Siegel, D. S. (2018). Academic Entrepreneurship: Lessons Learned for Technology Transfer Personnel and University Administrators, World Scientific Book Chapters, 2018, pp. 1-21.

[48] Siegfried, J. J., Sanderson, A. R. and McHenry, P. (2007). "The economic impact of colleges and universities", Economics of Education Review, vol. 26, no. 5, 2007, pp. 546-558. 
[49] Smith, H. L. and Ho, K. (2006). "Measuring the performance of Oxford University, Oxford Brookes University and the government laboratories' spin-off companies", Research Policy, vol. 35, no. 10, 2006, pp. 1554-1568.

[50] Sternberg, R. (2014). "Success factors of university-spin-offs: Regional government support programs versus regional environment", Technovation, vol. 34, no. 3, 2014, pp. 137-148.

[51] Varga, A. (1999). "Time-space patterns of US innovation: Stability or change?", Innovation, networks and localities, Berlin, Springer, 1999, pp. $215-$ 234.

[52] Vincett, P. S. (2010). "The economic impacts of academic spin-off companies, and their implications for public policy", Research Policy, vol. 39, no. 6, 2010, pp. 736-747.

[53] Woo, S., Jang, P. and Kim, Y. (2015). "Effects of intellectual property rights and patented knowledge in innovation and industry value added: A multinational empirical analysis of different industries", Technovation, vol. 43, 2015, pp. 49-63.

[54] Wright, M. (2007). Academic entrepreneurship in Europe, Edward Elgar Publishing, 2007. 